\title{
Presentation av Vinnie Nørskov
}

Vinnie Nørskov er lektor ved Aarhus Universitet og leder af Antikmuseet, et universitetsmuseum for de antikke oldtidskulturer omkring Middelhavet.

Hun er uddannet klassisk arkæolog med en magisterkonferens ved Aarhus Universitet, men studerede også en årrække ved Ludvig-Maximilians Universität i München. Her blev hun som studerende ansat ved de tyske udgravninger i Pergamon i det nuværende Bergama i Tyrkiet og arbejdede med de keramiske fund. Det førte senere til en deltagelse i den danske Halikarnassosekspedition i det nuværende Bodrum, hvor hun publicerede keramik fra den hellenistiske periode fra Mausoleet i Halikarnassos i 2002.

Interessen for det museologiske opstod i forbindelse med udarbejdelsen af magisterspecialet, som var en undersøgelse af kunstmarkedet for græsk bemalet keramik i efterkrigstiden, afleveret i 1995. En analyse af over 500 auktionskataloger viste, at store mængder keramik var kommet på markedet i 1970'erne og 80'erne, og at det var tæt forbundet med spor af plyndringer i specielt Syditalien. Det var en af de første forskningsundersøgelser af et fænomen, som viste sig at være del af et større kriminelt netværk, som blev afsløret af det italienske politi. Deres ransagning af et lager i Geneve i efteråret 1995 har efterfølgende vist sig at indeholde bevismateriale, som kunne afsløre udbredt handel med illegalt udgravede genstande gennem flere årtier. Specialet førte til et ph.d.-stipendium, som udvidede studiet til en undersøgelse af museernes indsamlingskriterier, og afhandlingen blev udgivet af Aarhus Universitetsforlag i 2002 med titlen Greek Vases in New Contexts. Nørskovs forskning har siden fokuseret på kunstmarkedet i 1800-tallet, dets opståen og udvikling og relationen mellem det kommercielle marked og udviklingen af klassisk arkæologisk forskning. Hun har blandt andet publiceret artikler om Lucien Bonapartes samlinger og distribution gennem salg på auktioner i $\mathrm{Pa}$ ris og arbejder i øjeblikket på en større analyse af auktionsmarkedets udvikling med særligt fokus på relationen til forskningen. Projektet arbejder med auktionskataloger som kildemateriale til andet end blot proveniensforskning. Hun deltager ligeledes i et projekt ved den Britiske skole i Rom omkring den amerikanske kunsthandler John Marshall og hans aktiviteter i begyndelsen af det 20. århundrede.

På baggrund af hendes forskning har Nørskov deltaget i blandt andet The Leiden Network for the Protection of Cultural Heritage, og i 2005 blev hun medlem af den danske nationalkomite af ICOM, som hun var været formand for 2009-2015. Hun interesserer sig særligt for etik og har undervist i museumsetik på Aarhus Universitet, Konservatorskolen i København og ved den danske museumsorganisations efteruddannelseskurser.

Som leder af Antikmuseet og eneste faglige ansatte er en stor del af arbejdet praktisk museumsarbejde, herunder alt fra projektudvikling, udstillingsopbygning, formidling, personaleansvar, indsamling og registrering. Hun er op- 


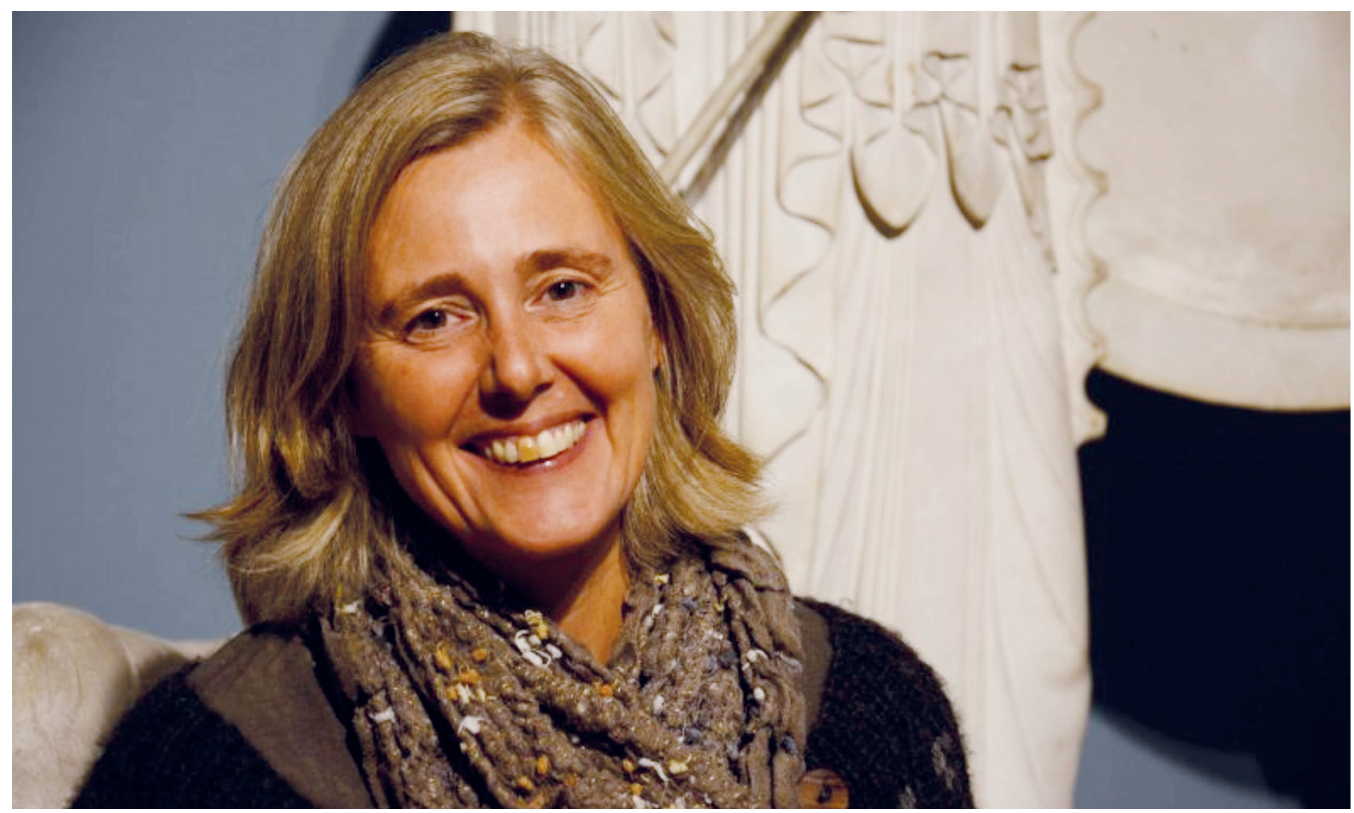

Fig. 1. Vinnie Nørskov. Foto: Kenneth Sletten Christensen.

taget af, hvordan universitetssamlinger kan udnyttes både i undervisning og forskning på universiteter og afholdt i 2014 en international konference om klassiske arkæologiske universitetssamlinger, som førte til oprettelsen af netværket INCAUC, International Network of Classical Archaeological University Collections. Hun har blandt andet arbejdet med at udvikle øvelsesbaserede kurser for arkæologistuderende med udgangspunkt i samlingerne.

Nørskov har siden 2004 været en del af Center for Museologi på Aarhus Universitet og underviser i museumsforvaltning, museumshistorie, museologisk teori og digital kommunikation. I udviklingen af de museologiske kurser har hun særligt haft fokus på relationen mellem det teoretiske og praktiske og gennem samarbejde med museerne på relevans og behov på museerne i dag. Samarbejdet ved Center for Museologi har også ført til forskning inden for samtidig museumsdrift. Hun deltog i det kollektive forskningsprojekt Det strategiske museum med kolleger fra Center for Virksomhedskommunikation og har sammen med Ane Hejlskov Larsen arbejdet med sponsering på museer i Danmark. Hun har ligeledes sammen med Ane Hejlskov Larsen udført konsulentopgaver for Kulturstyrelsen under det danske Kulturministerium om unges brug og ikke-brug af museer samt for Aarhus Kommune om museernes betydning for lokalområdet.

Vinnie Nørskov, ph.d., lektor og museumsleder klavn@cas.au.dk

Antikmuseet, Aarhus Universitet

Victor Albecks Vej 3, bygn. 1414

DK-8000 Aarhus C, Danmark 